ELORE (ISSN 1456-3010), vol. 15 - 1/2008.

Julkaisija: Suomen Kansantietouden Tutkijain Seura ry.

[http://www.elore.fi/arkisto/1_08/eng1_08.pdf]

\title{
KiRJA-ARVIO:
}

\section{KILTTEYDEN KAHLITSEMAT, USKONNOLLA PÄÄHÄN POTKITUT?}

Antola, Päivikki (toim.) 2007: Papinlapset. Helsinki: Ajatus Kirjat. 222 sivua.

\section{$\underline{\text { Pasi Enges }}$}

Vitam regit fortuna, non sapientia - elämää ohjaa kohtalo, ei viisaus. Miten antiikin fraasi pätee, kun on syntynyt pappisperheeseen ja lapsuusajan sosiaalisena viitekehyksenä on ollut perinteisiä arvoja vaaliva uskonnollinen yhteisö? Stereotyyppiset mielikuvat ankarasta kasvatuksesta ja kurinalaisesta elämästä nousevat helposti esiin, kun puheena on lapsuus herätyskristillisessä kodissa. Suomen viidellä herätysliikkeellä - sekä "vanhoilla" liikkeillä rukoilevaisuudella, herännäisyydellä, lestadiolaisuudella ja evankelisuudella että niin sanotulla viidennellä, uuspietistisellä herätysliikkeellä - on kaikilla omat kristinopin painotuksensa ja tulkintansa, samoin rituaaliset perinteensä. Minkälaiset eväät elämälle tarjoaa koti, jossa vanhemmuutta leimaa voimakas sitoutuminen seurakunnalliseen työhön ja sanan julistukseen? Varustaako lapsuusaika ja kotona saatu kasvatus yksilön hänen tulevissa elämänvaiheissaan ja -valinnoissaan ohjaavalla viisaudella, vai onko papin lapseksi syntyminen kohtalo, jonka seurauksia ei voi välttää sen paremmin hyvässä kuin pahassakaan?

Päivikki Antolan (ent. Suojanen) toimittama Papinlapset ei ole tieteellinen julkaisu, vaan kokoelma varsin erilaisista lähtökohdista kirjoitettuja ja erilaisia tyylilajeja noudattavia tekstejä. Yhteistä kirjoituksille on omakohtaisuus: kaikki kirjoittajat ovat papin lapsia ja useimpien lapsuudenkotina on ollut rovasti-isän virkaetuihin kuulunut pappila. Teoksen kahdelletoista kirjoittajalle on annettu vapaus valita oma lähestymistapansa aiheeseen, minkä seurauksena kokoelmaan sisältyy sekä lähdeviittauksin ja -luetteloin varustettuja asia-artikkeleja että kaunokirjallisuutta tai mielipidekirjoitusta läheneviä tekstejä.

Kirjoitukset ovat luonteeltaan omaelämäkerrallisia, kirjoittajien omaa lapsuutta ja sen aikuisuuteen ulottuvaa vaikutusta reflektoivia, ja siinä mielessä hyvin henkilökohtaisia. Toimittajan tutkijatausta on kuitenkin selkeästi näkyvissä kirjan lähtökohdissa ja rakenteessa. Alkuperäisenä tarkoituksena on ollut saada mukaan teksti sekä 


\section{KILTTEYDEN KAHLITSEMAT, USKONNOLLA PÄÄHÄN POTKITUT?}

papin pojalta että tyttäreltä kaikista herätysliikkeistä, vailla herätysliiketaustaa olevista ja siviilirekisteriin kuuluvista. Tavoite ei ole toteutunut täydellisesti, mutta kuitenkin varsin kattavasti. Kirjoittajia on rohkaistu assosioimaan vapaasti, mutta virikkeiksi on annettu joukko mahdollisia pohdinnan aiheita. Näitä ovat esimerkiksi lapsuudessa yksilöön juurrutettu maailmankuva ja arvot, papin lapsen asema ikäryhmänsä keskuudessa ja käsitykset synnistä. Kirjan asetelma on siis tavallaan "tutkimuksellisen" systemaattinen ja vertaileva.

\section{KIITOLLISUUTTA JA KAPINAA}

Kokoelman tekstit on ryhmitelty kirjoittajan taustan mukaisesti alkaen herännäisistä ja päätyen ilman herätysliiketaustaa varttuneisiin. Kutakin suuntausta edustaa yhdestä kolmeen kirjoitusta. Herännäisyystaustaisista kirjoittajista Mauno Jokipiin teksti on tiivis ja sisällöltään täsmällinen, paikoin kansatieteellinenkin kuvaus pappilan elämästä. Se on toimitettu kirjoittajan kuoleman jälkeen, mikä osaltaan selittänee tiiviiin tekstin paikoin yllättävät yksityiskohdat ja asiasiirtymät. Marja Myyryläisen episodeista rakentuvassa, puolittain kaunokirjallisessa esseessä "Kukkia ja mehiläisiä" punaisena lankana on isän mehiläisharrastus, joka toimii myös metaforisesti kirjoittajan oman muistelun ja reflektion välineenä. Anssi Sinnemäen paljastavasti otsikoitu artikkeli "Lapsuuteni pappilakulissit" puolestaan keskittyy Lapuan perinteikkääseen pappilarakennukseen, sen "ulkoiseen historiaan ja sisäiseen maailmaan". Muistot eivät ole ajan kultaamia ja päällimmäisenä tekstistä välittyy Lapualla koettu "askeesia korostava ahdasmielinen körttiläisyys". Sinnemäen sanoin, pappila "on elimellinen osa omaa kokemustani ja kohtaloani: sieltä olen saanut kantaakseni menneiden sukupolvien kuormaa itsessäni’”.

Evankelisesta traditiosta kumpuaa kolme kertomusta. Martti Arkkila, evankelista herätysliikettä edustava pappi jo viidennessä polvessa, välittää positiivisen ja kiitollisen kuvan lapsuudestaan ja päätymisestään papiksi. Hänen keskeinen teemansa on papinlapsiin liitetty "kiltteyden harha", joka aikuisiällä voi kostautua ristiriitoina ja liiallisesta sitoutumisesta seuraavana työuupumuksena. Anna Lindqvist puolestaan ilmoittaa kirjoituksensa päätarkoitukseksi tilinteon ja asioiden järjestelyn, mikä auttaa häntä ymmärtämään ahdistavaksi ja vaikeaksi kokemaansa lapsuutta näkemyksissään taipumattoman isän ja perheen kristillisten ihanteiden paineessa. Hän myös pohtii eksplisiittisesti oman muistelemisensa ja muistamisensa subjektiivisuutta, ja erittelee syitä, jotka aikuisiällä etäännyttivät hänet vanhempiensa uskosta. Paljon valoisammin lapsuutensa muistot välittää Pertti Mustajoki, jonka kirjoitus sisältää runsaasti yksityiskohtia leikeistä, harrastuksista, lempeästä kasvatuksesta ja turvallisesta aikuistumisesta. Mustajoki kertoo lähteneensä maailmalle ylioppilaana, jolla oli niukasti kokemusta sosiaalisesta elämästä, mutta eväinään vankat luterilaiset arvot.

Vanhoillislestadiolaisen papin poikana syntyneen ja aikuisiällä siviilirekisteriin siirtyneen Juha Maasolan muistoissa lapsuus näyttäytyy ahdistavana aikana, johon kuului jatkuva ruumiillinen kuritus. Hän ei kuitenkaan syyllistä isäänsä vaan pohtii 


\section{PASI ENGES}

perinteen taakkaa ihmisen elämää - myös omaa elämäänsä - ohjaavana voimana. Samaan liikkeeseen kuuluva Anne-Maria Takkula puolestaan kuvailee kotikasvatustaan sallivaksi ja perheen kaikkien yhdentoista lapsen kohtelua tasapuoliseksi; vanhemmat olivat tasapainoisia ja tervejärkisiä ihmisiä. Tästä tekstistä välittyy harmoninen lapsuus, jonka vaikutukset, uskonelämä mukaan lukien, ulottuvat kirjoittajan aikuisuuteen ja muisteluajankohtaan.

Kirjan avoiminta ja intiimeintä tilitystä lukija saa eteensä Päivikki Antolan kirjoituksessa "Miksi synnyinkään papintytöksi?". Länsi-Suomen rukoilevaisuudessa tunnetun rovasti Oskar Antolan esikoistytär on ansiokkaan tutkijanuran tehnyt uskontotieteilijä, antropologi ja folkloristi. Monet keskeisistä tutkimusaiheistaan hän on valinnut uskonnollisten liikkeiden piiristä; mainittakoon tässä väitöskirja rukoilevaissaarnaajista ja saarnojen tuottamisesta (1978) ja virsilaulua eri herätysliikkeissä käsittelevä tutkimus (1984). Nyt Antola luopuu tutkijanroolistaan ja kirjoittaa estoitta auki lapsuuttaan ja siitä juontuvia traumoja myöhemmässä elämässään. Hän kuvaa kirjoitustaan henkilökohtaiseksi tilinteoksi, yritykseksi järjestellä elämän kuvioita, jotta pääsisi niiden ytimeen ja voisi ymmärtää niitä. Kertomusta kannattelee kohtalodiskurssi.

Uuspietismi on herätysliikkeenä muita huomattavasti nuorempi ja selkeämmin urbaanissa ympäristössä toimiva kuin edellä mainitut. Niinpä liikettä edustavat kirjoittajat ovatkin kokoelman nuorimmat. Jouni Junkkaala kieltäytyy olemasta papinlapsi, vaikka onkin kasvanut "viidesläiseen" maailmankuvaan pienestä pitäen. Kodin perintönä on seurannut lupa myös epäillä ja olla eri mieltä. Anna Mäkelä niin ikään mieltää itsensä ennen kaikkea kristittyjen vanhempien lapseksi, ei papin. Vihreäksi feministiksi ja naispappeuden kannattajaksi tunnustautuva kunnallispoliitikko tiedostaa pappeihin ja pappien lapsiin kohdistuvat ennakkoluulot, mutta ei koe isän ammatin ja mielipiteiden vaikuttavan omiin näkemyksiinsä ja valintoihinsa.

Kokoelman päättää Juha Arhinmäki, jolla ei ole herätysliiketaustaa. Opiskeluaikana uskonnosta erkaantunut ja samalla poliittisesti aktivoitunut kirjoittaja ei ole uskonasioissa kokenut kodin painostusta, mutta myöntää kantaneensa läpi elämänsä papinpojan roolia.

\section{VAIHTELEVAT LAPSUUSKOKEMUKSET}

Papinlapset on kokoelma erityyppisiä kirjoituksia, joiden kirjoittajia yhdistää kokemus elämästä pappisperheen lapsena. Valtaosalle kirjoittajista kokoelmaan osallistumisen tärkein vaikutin on epäilemättä ollut terapeuttinen. Osa teksteistä on luonteeltaan lähinnä kuvailevia, mutta valtaosassa on mukana hyvinkin henkilökohtaista tilitystä. Osa etenee kronologisesti, toiset taas temaattisesti tai episodisesti. Kirjan kokoavan teeman ja sen, miten kirjoittajat ovat kirjoitustehtävänsä ymmärtäneet, kannalta kiintoisa yksityiskohta on monien kirjoittajien tapa käyttää termejä papin lapsi ja papinlapsi erilaisissa merkityksissä. Edellinen on sukulaisuussuhdetta ja perheen yhteiskunnallista statusta kuvaava, jokseenkin neutraali nimitys. Jälkimmäiseen taas liittyy voimakkaita 
KiLTEYDEN KAHLITSEMAT, USKONNOLLA PÄÄHÄN POTKITUT?

konnotaatioita: se korostaa erityisyyttä, keskiverrosta poikkeamista (sekä negatiivisessa että positiivisessa mielessä) ja on kelvannut esimerkiksi koulukiusaamisen välineeksi. Juha Maasola puolustelee tekstinsä "saarnaavaa" sävyä sillä, että "olen edelleen papin poika, jos kohta en enää papinpoika".

Teoksen kirjoituksissa lukijan huomio kiinnittyy tämän tästä hyvin tarkasti kuvattuihin yksityiskohtiin. Esineitä, tiloja, paikkoja, kulkureittejä, tilanteita, mielialoja ja tunteita välitetään verbaalisina lähikuvina. Miksi yksityiskohtien ja episodien muistaminen on niin tärkeätä? Tutkimuksessaan Muistoista rakentuva lapsuus Pirjo Korkiakangas on todennut lapsuuden muistelun usein kietoutuvan kontekstistaan irrotettuina vain triviaaleilta näyttäviin asioihin. Muistelijan kannalta niillä voi kuitenkin olla hyvinkin suuri merkitys. Muistikuvat eivät ole satunnaisia, vaan jäsentyneen muistokokonaisuuden osia, jotka olennaisella tavalla rakentavat yksilön elämänhistoriaa, persoonallisuutta ja identiteettiä. (Korkiakangas 1996, 17-18, 330.)

Herätysliiketausta sinänsä ei selitä eroja lapsuusajan muistelemisessa ja arvioinnissa, sen sijaan kirjoittajan syntymäajankohdalla ja siihen liittyen erilaisilla yhteiskunnallisilla oloilla näyttää olevan merkitystä. Lapsuusmuistojen valossa mihinkään herätysliikkeeseen kuuluminen tai kuulumattomuus ei sinänsä selitä lapsuuden mieltämistä onnelliseksi tai onnettomaksi, vapaaksi tai ahdistavaksi. Uskonto ja sen perustelemat lapsuuden arjen käytännöt ovat toki keskeinen, mutta eivät ainoa yksilön elämänvaiheita ja -valintoja ohjaava tekijä. Koska Papinlapset ei ole tutkimus, se ei tarjoa lukijalle valmiita vastauksia, vaan tusinan omakohtaiseen kokemukseen perustuvia, persoonallisia näkökantoja papinlapseuden iloihin ja suruihin. Johtopäätökset jäävät lukijan tehtäviksi.

\section{KirjallisuUs}

KORKIAKANGAS, PIRJO 1996: Muistoista rakentwva lapsuus. Agraarinen perintö lapsunden työnteon ja leikekien muistelussa. Kansatieteellinen arkisto 42. Helsinki: Suomen Muinaismuistoyhdistys.

SUOJANEN, PÄIVIKKI 1978: Saarna, saarnaaja, tilanne. Spontaanin saarnan tuottamisprosessi Länsi-Suomen rukoilevaisundessa. Suomalaisen Kirjallisuuden Seuran Toimituksia 343. Helsinki: Suomalaisen Kirjallisuuden Seura.

— 1984: Finnish Folk Hymn Singing. Study In Music Anthropology. Tampereen yliopiston kansanperinteen laitoksen julkaisu 11. Tampere: University of Tampere, Institute for Folk Tradition.

Filosofian maisteri Pasi Enges toimii folkloristiikan päätoimisena tuntiopettajana Turun yliopistossa. 